Editorial

\title{
Effects of Fiscal and Monetary Policy in the Great Recession
}

\author{
Gonzalo Caballero \\ Faculty of Economics, Campus As Lagoas, Marcosende, University of Vigo, Vigo 36310, Spain; \\ E-Mail: gcaballero@uvigo.es
}

Received: 24 September 2013 / Accepted: 24 September 2013 / Published: 24 September 2013

World economy is living a time of change, and the complexity of change has implied a new research agenda on the role of economic policy in society. The role, types and effects of economic policy have been major issues in economic science since its origins. Jean Tinbergen (1956) [1] established the basis for the traditional theory of economic policy in economics and he tried to show how economic knowledge could be organized to regulate and guide economic systems. Nevertheless, this traditional approach has been improved through several contributions, for example when Eggertsson (1997) [2] incorporated the existence of incomplete knowledge, endogenous politics and institutional change in the theory of economic policy.

In any case, there have been several relevant theoretical contributions on the theory of economic policy in recent decades, but the major focus in the history of economic ideas has been on the debate about the role, significance and effects of different types of economic intervention in a market economy. On the one hand, when John Maynard Keynes published his General Theory of Employment, Interest and Money in 1936 [3], he established a fundamental step in the defense of an active fiscal policy in economics. On the other hand, Milton Friedman proposed an alternative macroeconomic policy founded on the ideas of "monetarism" (Friedman, 1959, [4]) and he denotes the tradition of economic analysis that believes in market benevolence and denies any efficient role of fiscal policy. Keynes and Friedman have been two of the most relevant economists of all times, and the social and political influence of their conflicting approaches about the role and effects of economic policy is key to understand ideologies, policies and societies in the last century. The Keynesian revolution and the Chicago school of economics went beyond the limits of economics, and their arguments continue to be present in the foundations of political debate in the 21 st century.

Since the mid-1980s there has been a decline in the volatility of business cycle fluctuations in the US, and similar declines in the volatility of output and inflation occurred in other advanced countries. The world economy looks to be in a Great Moderation (Bernanke, 2004, [5]), and mainstream economists started to believe that (under-regulated) markets were working very well, as if they constituted an omniscient, perfect and benevolent mechanism. In fact, in his presidential address to the 
American Economic Association in 2003, Robert Lucas concluded that the "central problem of depression-prevention has been solved", therefore active economic policy had not an important role to play and the debate on economic policy was deactivated in a world where financial globalization had been developed with a scant level of regulation.

In September 2008, the international economy suffered a hugely important financial crisis, symbolized by the fall of Lehman Brothers, which brought with it panic in the banking sector, credit contraction and financial instability. The financial crisis, and its rapid impact on the real economy, generated a significant shrinkage of world economic activity in 2008. In the majority of developed economies this reduction in activity even led to an economic recession and an increase in unemployment.

When the economic and financial crisis broke in 2008, governments were aware of the need to tackle the global economic crisis in a coordinated way, understanding that the political action taken by just one country would not be sufficient to overcome the crisis scenario: dialogue and coordination between countries would be more necessary than ever to avoid a worldwide depression. In this way, it was assumed that independent action in economic policies taken by a hegemonic economic-financial leader in the world economy would be insufficient, plus the non-existence of multi-lateral organisms invested with effective decision-making capacity to exit the crisis was evident, so the coordination of macro-economic policies was revealed as the only possible way of cushioning the international economic crisis, reactivate credit flow and recover production and employment.

The search for coordination in economic policies in the face of the crisis led the main developed and emerging economies to activate forums for international economic cooperation and dialogue. To be specific, the G-20 held three summits between November 2008 and September 2009, all focusing on the economic crisis and the reform of the international financial system. In this way, governments' monetary and fiscal policy responses were quicker and better coordinated than in the Great Depression.

The governments of the world's leading economies shared the analysis and diagnosis of the existing situation, and at the G-20 meetings sought a cooperative response to ensure they would apply the right economic policies to deal with the crisis. The G-20 summit agreements guided governments' economic policies in order to try to restore growth in 2008-2009. The agreements of the G-20 emphasized the need for an institutional reform of international financial architecture, and in 2008 proposed an active State intervention, unprecedented since the 1970s, that injected public money through economic reactivation plans. In this sense, the blueprint for expansive monetary and fiscal policies (clearly inspired by Keynes) that the G-20 dictated as a means of tackling the crisis and allowing growth to recover, was applied in 2008 by the Summits' participating governments and others in absentia, and the result of this coordinated action largely explains how the world economy did not commit some of the errors of the Great Depression (Eichengreen and O'Rourke, 2009, [6]).

When studying and proposing responses to the Great Recession, a revival of the classical debate on the role and effects of economic policy has appeared in economics. After the crisis of September in 2008, in his intervention in the House Committee on Oversight and Government Reform, the Former Federal Reserve Chairman Alan Greenspan recognized that he "was shocked because I'd been going for 40 years or more with very considerable evidence that it was working exceptionally well", but he had to accept the deficiency of his approach to markets and regulation. "Yes, I found a flaw", he commented. 
The international crisis has followed different stages, and contributed to the European Sovereign debt crisis. Understanding the fiscal dimensions of the euro crisis has been a challenge for economic analyses (Lane, 2012, [7]) and the debate on the effects of the austerity policy has increased in Europe.

On the other hand, the debate on fiscal and monetary policy continues to be a hot topic in other countries, not just in the EU. For example, there is a broad analysis in the US about the convenience of the continuity of an active economic policy driven by the Federal Reserve under Bernanke in 2013.

Lastly, the International Monetary Fund has provided some ideas on the role of fiscal policy in the Great Recession (IMF, 2013, [8]). Three conclusions should be pointed out. Firstly, the crisis has provided evidence that fiscal policy is an appropriate countercyclical policy tool under some circumstances. Secondly, countercyclical fiscal policies could be more effective and the most appropriate policy depends on the kind of recession: there is not only one effective economic policy program to be applied in all crises. Thirdly, it has been concluded that the surge in central bank purchases of government debt has helped restore financial market functioning, but the Fund recommends that central bank support should be a complement to fiscal adjustment. In this sense, the economic policy agenda of Central Banks should not be a substitute for fiscal adjustment (IMF, 2013).

Recently, new interesting contributions on fiscal and monetary policies have been published. Alesina (2012) [9] assumes that fiscal policies have regained a central role in the debate as a tool to recover from the Great Recession, and discusses why spending-based adjustments are preferable and less likely to be costly than tax-based ones. Oh and Reis (2012) [10] present a model where targeted lump-sum transfers are expansionary both because of a neoclassical wealth effect and because of a Keynesian aggregate demand effect. Shoag (2013) [11] estimates fiscal multipliers, using State pensions shocks since the Great Recession. Coenen et al. (2012) [12] estimate that discretionary fiscal measures have increased annualized quarterly real GDP growth during the crisis by up to 1.6 percentage points. Corsetti et al. (2013) [13] analyses the impact of strained government finances on macroeconomic stability and the transmission of fiscal policy. Stein (2012) [14] develops a model that addresses the goals and methods of financial stability policies.

The research agenda on the role of fiscal and monetary policies in the Great Recession continues to be drawn. We need more theoretical and applied research on the effects of economic policy during crisis, and different approaches that can expand the frontier of knowledge. All types of contributions on this topic are welcomed.

\section{References}

1. Tinbergen, J. Economic Policy: Principles and Design; North Holland Publishing Company: Amsterdam, the Netherlands, 1956.

2. Eggertsson, T. The old theory of economic policy and the new institutionalism. World Dev. 1997, $25,1187-1203$.

3. Keynes, J.M. The General Theory of Employment, Interest and Money; Palgrave Macmillan: London, UK, 1936.

4. Friedman, M. A Program for Monetary Stability; Fordham University Press: New York, NY, USA, 1959. 
5. Bernanke, B. Remarks by Governor. Presented at the Meeting of the Eastern Economic Association, Washington, DC, USA, 20 February 2004.

6. Eichengreen, B.; O'Rourke, K.H. A Tale of Two Depressions: What Do the New Data Tell Us? Available online: http://www.voxeu.org/article/tale-two-depressions-what-do-new-data-tell-usfebruary-2010-update (accessed on 24 September 2013).

7. Lane, P.R. The european sovereign debt crisis. J. Econ. Perspect. 2012, 26, 49-67.

8. IMF Policy Paper. Reassessing the Role and Modalities of Fiscal Policy in Advanced Economies. Available online: http://www.imf.org/external/np/pp/eng/2013/072113.pdf (accessed on 24 September 2013).

9. Alesina, A. Fiscal policy after the great recession. Atl. Econ. J. 2012, 40, 429-435.

10. Oh, H.; Reis, R. Targeted transfers and the fiscal response to the great recession. J. Monet. Econ. 2012, 59, S50-S64.

11. Shoag, D. Using State pension shocks to estimate fiscal multipliers since the great recession. Am. Econ. Rev. 2013, 103, 121-124.

12. Coenen, G.; Straub, R.; Trabandt, M. Fiscal policy and the great recession in the Euro area. Am. Econ. Rev. 2013, 102, 71-76.

13. Corsetti, G.; Kuester, K.; Meier, A.; Müller, G.J. Sovereign risk, fiscal policy, and macroeconomic stability. Econ. J. 2013, 123, F99-F132, doi:10.1111/ecoj.12013.

14. Stein, J.C. Monetary policy as financial stability regulation. Q. J. Econ. 2012, 127, 57-95.

(C) 2013 by the authors; licensee MDPI, Basel, Switzerland. This article is an open access article distributed under the terms and conditions of the Creative Commons Attribution license (http://creativecommons.org/licenses/by/3.0/). 